\title{
KONSTUKSI PEMAKNAAAN MASYARAKAT PRIBUMI: MAKNA MASYARAKAT PENDATANG BAGI ANGGOTA MASYARAKAT PRIBUMI DESA NEROKTOG KECAMATAN PINANG KOTA TANGERANG
}

\author{
${ }^{1}$ Een Irianti \\ 1 Universitas Islam Syekh Yusuf Tangerang, \\ Email:eenerianti@unis.ac.id
}

\begin{abstract}
This article examines the meaning of immigrant society for members of indigenous communities by taking the case in the village of Neroktog, Pinang Subdistrict, Tangerang City, using descriptive qualitative assessment, this research is carried out by exploring the phenomenon construction the reality of social interactions that occur between indigenous and migrant communities. The results show that the meaning of self, the meaning of information and the meaning of immigrants are described differently by each member of the indigenous community. Differences in perceptions that occur indicate that experience, attitudes, power, information, the meaning of self become a construction space where attendance is interpreted by indigenous people.
\end{abstract}

Keywords: Society, Indigenous, Immigrant, Meaning, Contruction. 


\section{A. PENDAHULUAN}

Desa Neroktog merupakan sebuah desa kecil di wilayah kota Tangerang, awalnya desa ini hanya dihuni oleh suku betawi. Namun, seiring arus urbanisasi yang pesat masyarakat dari berbagai daerah mulai berdatangan dan menetap di desa tersebut.

Pertama kali pendatang yang tinggal dan menetap adalah orangorang suku sunda, dan selama berpuluh-puluh tahun masyarakat pribumi yang merupakan suku betawi hidup rukun dan harmonis dengan orang sunda yang notabennya adalah masyarakat pendatang. Namun seiring berjalannya waktu dan interaksi yang terbangun orang sunda mulai mengenal karakter masyarakat pribumi. Orang sunda mulai mengidentifikasi karakter orang betawi yang menurutnya berkepribadian kasar, temperamental, hal tersebut timbul lantaran orang sunda sering melihat orang betawi yang menganiaya istri, peristiwa ini membuat suku sunda memiliki stereotip terhadap suku betawi bahkan merekatidak mengijinkan anak dan keturunanannya menikah dengan masyarakat pribumi.

Kesenjangan menjadi semakin besar pada saat masyarakat yang berasal dari jawa mulai berdatangan, ketika jumlahnya masyarakat pendatang dari suku jawa masih tergolong sedikit interaksi sosial yang terjalin sangatlah baik, saat itu masyarakat pendatang masih sangat menghormati masyarakat pribumi dan cenderung mengikuti budaya kelompok dominan yakni kebudayaan betawi, tokoh masyarakat dan tokoh agama dari kalangan masyarakat pribumi masih sangat disegani. Bahkan pejabat dilingkungan terkecil seperti ketua Rukun Warga dan Rukun Tetangga masih dipercayakan kepada masyarakat betawi sebagai pribumi.

Lambat laun masyarakat pendatang semakin semakin memenuhi desa Neroktog terutama didominasi oleh masyarakat suku jawa yang terus berdatangan, hal tersebut membuat kondisi perlahan berubah suku betawi yang semula merupakan masyarakat pribumi dengan jumlah mayoritas justru menjadi minoritas karena jumlahnya jumlah masyarakat pendatang yang lebih banyak. Tidak hanya dari segi jumlah kondisi masyarakat pendatang yang lebih baik dari sisi ekonomi membuat status sosial mereka semakin tinggi. Perubahan mulai terlihat mulai dari bangunan rumah dengan tembok-tembok tinggi dan harta benda yang mereka miliki sehingga terlihat arogan, sedangkankehidupan orang betawi sebagai masyarakat pribumi justru tidak mengalami perubahan yang berarti.

Keadaan tersebut semakin membuat masyarakat pribumi merasa dikucilkan, khawatir perannya tergantikan masyarakat pribumi mulai 
KONSTUKSI PEMAKNAAAN MASYARAKAT PRIBUMI:

MAKNA MASYARAKAT PENDATANG BAGI ANGGOTA MASYARAKAT PRIBUMI DESA NEROKTOG KECAMATAN PINANG KOTA TANGERANG

\section{Een Irianti}

menunjukkan sikap arogansinya mereka memaknai dirinya sebagai pemilik wilayah sehingga merasa berkuasa dan selalu ingin dihormati. Misalnya saja ketika berpapasan masyarakat pribumi beranggapan bahwa pendatanglah yang harus menyapa terlebih dahulu sebagai bentuk penghormatan kepada mereka, bahkan mereka tidak takut untuk menegur pendatang manakala dianggap arogan. Sikap seperti ini yang menyebabkan semakin sulitnya masyarakat pribumi menerima kehadiran masyarakat pendatang dari suku dan kebudayaan berbeda untuk masuk dalam sebuah lingkungan masyarakat.

Idealnya para pendatang menyesuaikan diri dengan kultur dominan, namun kenyataannya sebaliknya mereka yang menjadi masyarakat pendatang dengan kelas menengah ke atas cenderung kokoh mempertahankan identitas budayanya. Mereka dapat mempertahankan kebudayaannya karena posisi sosial, ekonomi dan politik, sehingga membuat mereka terbebas dari keharusan untuk tunduk pada kultur dominan. (Suparlan, 1999:124)

Keadaan tersebuat membuat masyarakat semakin terkotakkotakkan, pribumi berusaha mempertahankan nilai kebudayaan dan eksistensinya dengan cara mengelompokkan pribumi ke dalam kegiatankegiatan masyarakat misalnya dengan cara membentuk radio komintas, seolah ingin bersaing pendatang juga membuat koperasi yang menghimpun semua masyarakat pendatang yang ada di desa Neroktog.

Karena itu tidak mengherankan jika MT Arifin (1999:34) mengkhawatirkan beberapa etnik pribumi akan mengaktifkan solidaritas etnik, mereka mengelompok dalam berbagai etnik, dengan orientasi etnisistas yang cukup tinggi, cenderung eksklusif, dan memiliki stereotip terhadap kelompok lain.

Dengan membentuk kelompok etnik sebagai bentuk eksistensi diri, membuat gap yang terjadi justru semakin besar hal ini terlihat dalam kegiatan pengajian yang diikuti bersama baik oleh pribumi maupun pendatang, namun karna jumlah anggota jamaah pengajian yang mayoritas adalah pendatang membuat pribumi merasa terusik, ditambah komunikasi yang dilakukan pendatang dalam kegiatan pengajian lebih banyak menggunakan bahasa daerah sehingga sering kali membuat pribumi merasa tersinggung dan memiliki prasangka negatif terhadap pendatang.

Konflik semakin besar ketika jabatan-jabatan penting justru dikendalikan oleh pendatang karna jumlahnya yang lebih banyak pendatang berhasil memenangkan pemilihan ketua Rukun Tetangga sehingga secara otomatis jabatan publik kini dikuasai oleh pendatang dimana sebelumnya jabatan tersebut dipegang oleh pribumi. Dan kondisi 
ini membuat pribumi merasa semakin resah dengan keberadaan pendatang yang mulai menggeser posisi pribumi. Konflik antar etnik di Indonesia umunya terdiri dari tiga sebab utama diataranya: konflik muncul karena adanya benturan budaya, karena masalah ekonomi politik, dank arena kesenjangan ekonomi sehingga timbul kesenjangan sosial. (Sukamdi, 2002: 56).

Berbagai perubahan sosial yang terjadi membuat pribumi memilik pemakna terhadap pendatang khususnya suku jawa mereka beranggapan jika posisi jabatan publik dikuasai oleh orang jawa mereka akan semakin arogan dan akan semakin mengucilkan pribumi. Meskipun ada pula masyarakat pribumi yang mampu hidup berdampingan secara harmonis dengan masyarakat pendatang dan melihat realitas kehidupan masyarakat pendatang sebagai sebuah motivasi dan kondisi yang wajar.

Realitas masyarakat yang terjadi di desa Neroktog tersebut menarik peneliti agar dapat mengidentifikasi permasalahan secara lebih mendalam dengan menggunakan pendekatan fenomenologi dengan cara mengetahui bagaimana makna diri masyarakat pribumi desa Neroktog, Kecamatan Pinang, Kota Tangerang? Bagaimana masyarakat pribumi memaknai informasi tentang masyarakat pendatang? bagaimana makna masyarakat pendatang bagi anggota masyarakat pribumi desa Neroktog Kecamatan Pinang Kota Tangerang?.

\section{B. LANDASAN TEORITIS}

Sebagai bidang filsafat modern, fenomenoloi menyelidiki pengalaman kesadaran, yang berkaitan engan pertanyaan bagaimana pembagian antara subjeck (ego) dengan objek (dunia) muncul dan bagaimana sesuatu hal di dunia ini diklasifisikan. Para tenomenolog berasumsi bahwa kesadaran bukanlah di bentuk karna kebetulan dan dibentuk oleh suatu hal lainnya daripada dirinya sendiri. Demikian juga, dalam kehidupan sehari-hari, seorang tidak ada control diri terhadap kesadaran terstruktur. Edmund huserll menyatakan bahwa flosofinya merupakan strategi untuk "mengamankan" kesadaran dan dunia kebermaknaan dan nilai-nilai yang hidup dalam kehidupan sehari-hari (Moleong, 2009: 14-16)

Fenomenologi mencoba menepis semua asumsi yang mengkontaminasi pengalaman konkret manusia. Fenomenologi menekankan upaya menggapai "hal itu sendiri" lepas dari segala presuposisi. Semua penjelasan tidak boleh dipaksakan sebelum pengalaman menjelaskannya sendiri dari dan dalam pengalaman itu sendiri. (Littlejohn, 1999: 97) 
KONSTUKSI PEMAKNAAAN MASYARAKAT PRIBUMI:

MAKNA MASYARAKAT PENDATANG BAGI ANGGOTA MASYARAKAT PRIBUMI DESA NEROKTOG KECAMATAN PINANG KOTA TANGERANG

Konstrutksi Realitas $\begin{gathered}\text { Een Irianti } \\ \text { konsep mengenai konstruksionis }\end{gathered}$ diperkenalkan oleh sosiologi interpretative, Peter L. Berger bersama Thomas Luckman, mereka banyak menulis karya menghasilkan tesis mengenai konstrituksi tentang sosial atas realitas (Eriyanto 2004: 13).

Konstritruksi sosial adalah proses menciptakan pengetahuan dan realitas sosial melalui interaksi simbolis dalam suatu kelompok sosial. Jadi, pengetahuan dan realitas muncul dari persepsi manusia. Realitas adalah hasil ciptaan manusia kreatif melalui kekuatan kontruksi seosial terhadap dunia sosial disekelilingnya. Dan kekuatan utama yang sangat berperan dalam dunia sosial adalah media massa, Berger memandang masyarakat sebagai produk manusia dan manusia sebagai produk masyarakat, yang tentunya melalui komunikasi dalam hal ini media massa (Berger \& Luckmann, 1990:87).

Komunikasi Antar Budaya menurut Alo Lliweri dalam bukunya dasar-dasar komunikasi antar budaya mengatakan bahwa "sebagai bagian dari tuntutan gelabalisasi yang semakin tidak terkendali seperti saat ini, mendorong kepada kita terjadinya sebuah interaksi lintas budaya, lintas kelompok, serta lintas sektoral. Belum lagi perubahan-perubahan global lainya yang semakin deras dan menjadi bukti nyata bahwa semua orang harus mengerti karakter komunikasi antar budaya secara mendalam." (Alo Liliweri 2002:5).

Karena itu, terjadinya kesenjangan dalam masyarakat seringkali disebabkan oleh datangnya perubahan dari luar. Struktur sosial baru bedasarkan profesi dan fungsi yang lebih rational mengakibatkan perubahan relasi. Dalam kaitannya dengan komunikasi antar budaya, perubahan-perubahan yang datang dari dalam maupun luar. Sangat berpengaruh terhadap perubahan relasi antar budaya akibat kontak, interaksi dan hubungan antar anggota masyarakat yang berbeda kebudayaanya, muncullah komunikasi antarbudaya. (Sendjaja.2007:7-11) Stereotype berbagai disiplin ilmu memiliki pendapat yang berbeda mengenai asal mula stereotipre: psikolog menekankan pada pengalaman dengan suatu kelompok, pola komunikasi tentang kelompok tersebut, dan konflik antar kelompok. Sosiolog menekankan pada hubungan di nantara kelompok dan posisi kelompok-kelompok dalam tatapan sosial para humanis berorientasi psikoanalisis menekankan bahwa stereotype secara definisi tidak penah akurat, namun merupakan penonjolan ketakutan seorang kepada orang lainnya. Tanpa memperdulikan kenyataan yang sebenernya. (Gahral Aldian, 2002:11)

Makna dan Pemaknaan proses memberikan makna merupakan upaya lebih jauh dari penafsiran dan mempunyai kesejajaran dengan 
ekstrapolai. Pemakaman lebih mnuntut kemampuan integrative manusia dari segi indrawinya, daya fikirnya, dan akal budinya. Sama seprti ekstrapolasi, materi yang tersajikan dilihat tidak lebih. Dari tanda-tanda atau indicator bagi sesuatu yang lebih jauh. Dibalik yang tersaji bagi ekstrapolasi terbatas dalam arti emperik, sedangkan pada pemaknaan dapat pula menjangkau yang etik dan yang transcendental (Muhadjir, 2008: 187-188)

Makna Diri pengertian dari makna diri Menurut William D.Brooks mendefinisikan makna diri adalah: "Those physical, social, and physiological perceptioans of ourselves that we have derived from experiences and interaction with other.Pandangan perasaan kita tentang diri kita. Persepsi tentang diri boleh bersifat psikologi, sosial, dan fisik." (Rakmat, 2008: 101)

Banyak pengertian yang diberikan leh para ahli mengenai makna diri. Fitts (Agustiani, 2006: 26) mengemukakan bahwa makna diri merupakan kerangka acuan (Frame of reference) dalam berinteraksi dengan lingkungan. Agustina menjelaskan bahwa makna diri merupakan gambaran yang dimiliki seseorang mengenai dirinya, yang dibentuk melalui pengalaman-pengalaman yang dia peroleh dari interaksi dengan lingkungan.

\section{METODE PENELITIAN}

Peneliti mencoba realitas yang terjadi di desa neroktog adanya ketidak harmonisan yang terjadi antara masyarakat pribumi dan masyarakat pendatang dimana di dalamnya meliputi interaksi sosial yang begitu kompleks realitas tersebut sesungguhnya hasil konstruksi yang sengaja diciptakan sebagai sebuah proses terbentuknya sebuah pemaknaan dalam diri masyarakat pribumi khususnya dalam memaknai keberadaan masyarakat pendatang.

Dalam pendekatan fenomenologi di jelaskan bahwa pemaknaan meliputi, makna diri merupakan cara bagaimana masyarakat pribumimemaknai dirinya sendiri atau memberikan gambaran bagaimana tentang dirinya, makna informasi adalah cara bagaimana masyarakat pribumi memaknai segala informasi tentang masyarakat pendatang, setelah itu akan terlihat bagaimana makna masyarakat pendatang bagi anggota masyarakat pribumi di desa neroktog.

Metode penelitian yang digunakan oleh penulis dalam penelitian ini adlah metode kualitatif. Penelitian kualitatif juga menambakan sebagai berikut: Penelitian kualitatif yang bermaksud untuk memahami fenomena tentang apa yang dialami oleh subjek penelitian misalnya: perilaku, persepsi, motivasi, tindakan dan lain-lain secara holistic dan dengan cara 
KONSTUKSI PEMAKNAAAN MASYARAKAT PRIBUMI:

MAKNA MASYARAKAT PENDATANG BAGI ANGGOTA MASYARAKAT PRIBUMI DESA NEROKTOG KECAMATAN PINANG KOTA TANGERANG

\section{Een Irianti}

deskripsi dalam bentuk kata-kata dan bahasa. Pada suatu konteks yang alamiah dan memanfaatkan berbagai metode ilmiah. (Moleong 1989: 24)

Pendekatan penelitian yang dipakai oleh penulisan adalah fenomenologi Penelitian fenomenologi mencoba menjelaskan atau mengungkap makna konsep atau fenomena pengalaman yang didasari oleh kesadaran yang terjadi pada beberapa individu. Penelitian ini di lakukan dalam situasi yang alami, sehingga tidak ada batasan dalam memaknai atau memahami fenomena yang dikaji.

Informan dalam penelitian ini adalah 7 orang masyarakat pribumi yang tinggal desa posive sampli neroktog khususnya warga lingkungn RW02 penentuan informan ditatapkan secara sengaja (purposive sampling) berdasarkan atas kriteria yang telah ditentukan. Adapun kriteria informan dalam penelitian ini (1) Berusia minimal 25 tahun (2) dapat berkomunikasi dengan baik serta memiliki keluangan waktu (3) diambil masyarakat,tokoh pemuda dan beberapa orang masyarakat biasa.

Observasi dalam penelitian ini menggunakan cara langsung terhadap observasi yang relevan dengan kondisi lingkungan di lokasi penelitian yang diamati, peneliti terlibat secara langsung dalam proses pengumpulan data yang dibutuhkan dalam penelitian seperti mengklasifikasikan warga di lingkungan RW 02 bedasarkan etnik, selain itu peneliti juga ikut berperan serta baik secara aktif maupun pasif dalam interaksi sosial baik formal tidak formal yang melibatkan masyarakat pendang dan masyarakat bumi.

Wawancara yang digunakan dalam penelitian ini adalah wawancara tidak terstruktur. Peneliti menanyakan topic awal pada responden, lalu menggali secara mendalam informasi yang ada responden tanpa terlalu terikat dengan topic penelitian. Metode ini sering digunakan untuk menentukan judul penelitian, atau pada penelitian kualitatif, dimana peneliti merupakan bagian dari peneliti itu sendiri.

Dalam penelitian ini peneliti melakukan proses wawancara pra penelitian dengan beberapa orang informan guna melengkapi data yang dibutuhkan di awal penelitian, dalam hal ini peneliti mencoba menggali lebih dalam informasi, persepsi dan pandangan dari beberapa informan dengan melakukan wawancara baik dengan masyarakat pribumi sebagai subyek penelitian maupun dengan anggota dari masyarakat pendatang untuk kelengkapan data penelitian.

Secara umum langkah-langkah analisis data kualitatif seperti; Mengorganisasikan data, Memilah-milah menjadi satuan yang dapat dikelola, Mensistensiskannya, Mencari dan menemukan pola, Menemukan apa yang penting dan apa yang dipelajari, Memutuskan apa yang dapat 
diceritakan kepada orang lain. Analisis data dilakukan peneliti untuk menarik kesimpulan-kesimpulan dalam penelitian kualitatif, analisis data dikembangkan dengan maksud hendak memberikan makna terhadap data, menafsirkan atau mentransformasikan data. (Moleong, 2006:248)

Dalam menguji keabsaan data peneliti menggunakan teknik Ketekunan Pengamatan; berarti bahwa peneliti hendaknya mengadakan pengamatan dengan teliti dan rinci secara berkesinambungan terhadap factor-faktor yang menonjol. Kemudian ia menelaahnya secara rinci sampai pada suatu titik sehingga pada pemeriksaan tahap awal tampak salah satu seluruh faktor yang telah sudah dipahami. Ketekunan pengamatan bermaksud "menentukan ciri-ciri dan unsur-unsur dalam situasi yang relevan dengan persoalan atau isu yang sedang dicari dan kemudian memusatkan diri pada hal-hal tersebut dengan rinci (Moeleong, 2005:329).

\section{HASIL PENELITIAN}

\section{Makna Diri Masyarakat Pribumi}

Anggota masyarakat pribumi cenderung memandang dirinya sebagai pemilik wilayah seperti halnya yang diungkapkan mardiniwinata yang menjadi bagian dari anggota kelompok masyarakat pribumi sehingga merasa bahwa masyarakat pendatang harus menghormati dan menghargai masyarakat pribumi.

Tidak hanya persoalan rasa memiliki kehadiran masyarakat pendatang memberikan impilkasi pada paradigma berfikir masyarakat pribumi ditambah perubahan kondisi sosial, ekonomoni dan politik yang perlahan mulai mengalami pergeseran peran membuat persaingan dinatara dua kelompok masyarakat semakin tidak bias terhindarkan sehingga masing-masing kelompok berusaha menunjukkan kekuatan dan kelebihan kelompoknya. Beberapa anggoata kelompok pribumi diantaranya Hanafi dan Rodiyah memknai dirinya lebih unggul dalam hal keagamaan menganggap dirinya lebih agamis dari masyarakat pendatang. Selain itu Hendra yang juga anggota masyarakat pribumi memandang bahwa kelompok mereka yang lebih layak menjadi pemimpin karena dianggap dapat berlaku adil. Bahkan ada pula anggota masyarakat pribumi seperti pernyataan Aini yang melabeli dirinya dan kelompoknya sebagai orang yang jujur dan apa adanya yang kemudia hal itu dianggap tidak dimiliki oleh masyarakat pendatang.

Namun kenyataannya tidak semua anggota kelompok pribumi sependapat dengan anggapan tersebut, Aziz misalnya justru menilai pribumi sebagai orang yang bermulut besar yang hanya pandai bicara namun tidak sesuai dengan kenyataan, Ayuhan salah seorang anggota 
KONSTUKSI PEMAKNAAAN MASYARAKAT PRIBUMI:

MAKNA MASYARAKAT PENDATANG BAGI ANGGOTA MASYARAKAT PRIBUMI

DESA NEROKTOG KECAMATAN PINANG KOTA TANGERANG

\section{Een Irianti}

kelopok masyarakt pribumi pun menilai bahwa pribumi adalah pemalas dan tidak mandiri.

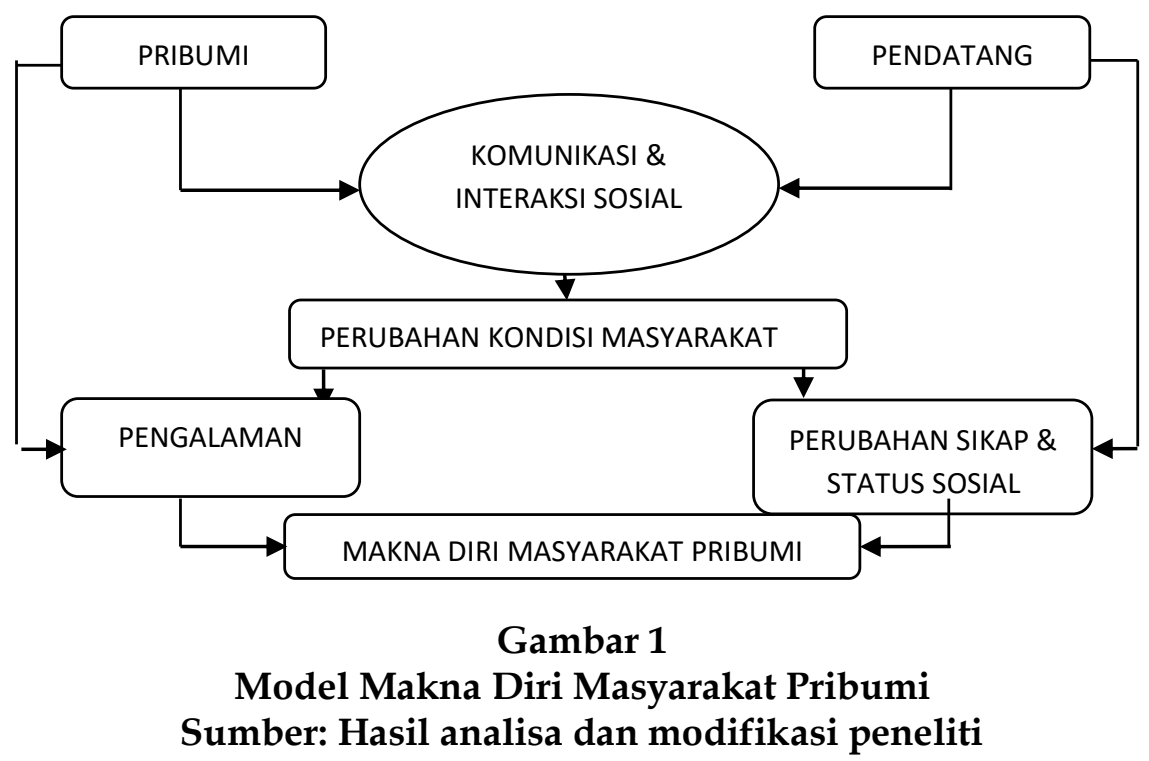

\section{Makna Informasi Pendatang bagi Anggota Masyarakat Pribumi}

Dalam melakukan proses interaksi sosial masyarakat terlibat dalam proses komunikasi yang dinamis tentu saja kemungkinan terjadinya pertukaran informasi, pandangan, pendapat dan lainnya. Indicator yang dipandang dapat mempengaruhi masyarakat pribumi dalam memaknai masyarakat pendatang antara lain dipengaruhi bergam informasi dari luar yang diterima masyarakat pribumi baik bersumber dari orang lain, keluarga, media dan sumber informasi lain, sehingga dapat menimbulkan kesan tertentu yang kemudian dipersepsi sebagai bahan untuk memberikan penilaian terhadap individu atau kelompok lain.

Dalam hal ini presfektif informasi dianggap sebagai salah satu referensi untuk memberikan pemaknaan kepada masyarakat pendatang, seperti halnya informasi yang diperoleh Hanafi dari hasil interkasinya dengan salah seorang opinion leader dari kelompok pribumi yang mengatakan bahwa karakter masyarakat pendatang seperti penjajah. Sama hal nya dengan Aini yang memperoleh informasi dari kerabat yang memiliki ikatan perkawinan dengan masyarakat pendatang sehingga membuat dirinya menganggap pendatang sebagai orang yang tidak jujur.

Tetapi tidak semua informasi yang didapat kemudian diterjemahkan secara benar perbedaan cara pandang dalam menerjemahkan informasi menjadi sebuah pengetahuan sangattergantung 
pada bagaimana cara individu memaknainya, seperti halnya informasi yang diperoleh Aziz dari hasil interaksi dengan ayahnya dirinya justru menilai bahwa pendatang itu mandiri, kaum laki-laki merupakan pekerja keras, dan kaum wanita adalah sosok yang pintar mengelola keungan. Senada dengan hal tersebut informasi yang diperoleh hendra justru didapatnya dari rekan kerjanya yang berasal dari suku batak yang mengangap bahwa pendatang adalah perkerja keras, giat, loyal dan pandai mengambil hati pimpinan.

Berbagai informasi negetif tentang masyarakat pendatang yang diperoleh Nimin Sukrna membuatnya memiliki anggapan yang berbeda dirinya justru memandang masyarakat pendatang sebagai kelompok yang kerap kali membuat keributan, dan meresahkan masyarakat. Hal tersebut juga dibenarkan rodiyah dari informasi yang disaksikan melalui media televisi dirinya menganggap pendatang sering kali melakukan berbagai aksi kriminal. Tidak hanya itu mardiniwinta juga memperoleh informasi dari rekan kerjanya bahwa pendatang adalah pengeret yang dinilai sering menuras harta pribumi.

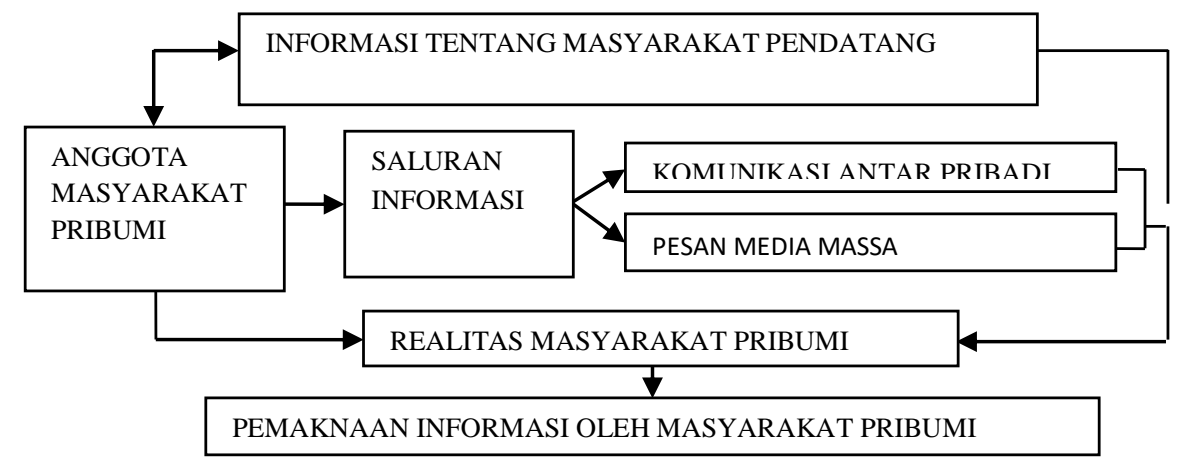

Gambar 2

Model masyarakat pribumi memaknai informasi tentang pendatang Sumber: Modifikasi peneliti

\section{Makna Pendatang Bagi Anggota Masyarakat Pribumi}

Menggali informasi tentang bagaimana anggota masyarakat pribumi memaknai kehadiran masyarakat pendatang menjadi sebuah pekerjaan yang menarik, hasilnya anggota kelompok pribumi tentu saja memiliki pemaknaan beragam, ada sebagian anggota masyarakat yang begitu sangat menyukai karakter masyarakat pendatang seperti yang diungkapkan Hendra yang memaknai pendatang sebagai orang yang giat bekerja, rajin, dan kuat. Aziz pun memiliki pemaknaan yang sama dirinya menilai bahwa pendatang memiliki tekad yang kuat, mandiri dan 
KONSTUKSI PEMAKNAAAN MASYARAKAT PRIBUMI:

MAKNA MASYARAKAT PENDATANG BAGI ANGGOTA MASYARAKAT PRIBUMI DESA NEROKTOG KECAMATAN PINANG KOTA TANGERANG

\section{Een Irianti}

sederhana. sikap masyarakat suku jawa sebagai pekerja keras memiliki mental yang kuat kini telah menjadi pendapat umum yang menjadi ciri khas pendatang.

Kenyataannya keberhasilan pendatang tidak cukup kuat untuk merubah persepsi masyarakat pribumi meskipun kagum pada sikap pendatang yang pekerja keras Nimin sukarna masih menilai ada sisi negatif pendatang dimana keberhasilannya justru membuat pendatang menjadi angkuh dan sombong. Berbeda dengan Rodiyah yang memaknai pendatang sebagai pekerja keras dan mampu hidup sederhana yang membuatnya sukses. Ayuhan pun memiliki pemaknaan yang sama karena dirinya melihat sedikit sekali pendatang yang membeli di warungnya membuatnya melabeli pendatang sebagai orang yang hidupnya irit dan sederhana.

Kelebihan yang dimiliki masayarakat pendatang tidak selalumendapatkan respon positif karena adapula anggoata kelompok masyarakat pribumi yang melihat perbuahan sosial yang terjadi pada masyarakat pendatang membuat perubahan sikap dan perlakukan mereka terhadap kelompok pribumi. Hanafi memaknai pendatang sebagai orangorang yang sombong karena tidak lagi menghormati pribumi. Begitupun mardiniwinata dirinya memaknai pendatang sebagai orang yang sombong dan sering bersikap diskriminatif. Lebih dalam Aini lebih memaknai pendatang bisa sukses karena hidupnya yang terlalu irit.

Secara umum seperti yang tergambar di atas makna masyarakat pendatang masih sangat bervariasi dan bersifat subjektif, hal tersebut bergantung pada pengalaman, informasi dan bagaimana masyarakat pribumi memaknai dirinya. Dari hasil wawancara yang dilakukan oleh peneliti terungkap fakta bahwa informan tidak hanya mendeskripsikan dan memaknai pendatang secara positif melaikan juga ada yang memaknainya negativ.

Dari hasil wawancara di atas dapat disimpulkan bahwa makna masyarakat pendatang dapat dipersepsi secara berbeda oleh setiap anggota kelompok pribumi perbedaan tersebut merupakan fenomena yang berangkat dari perspektif yang berbeda dalam melihat realitas yang terjadi dimasyarakat dimana setiap orang memiliki indikator tersendiri dalam melakukan penilaian.

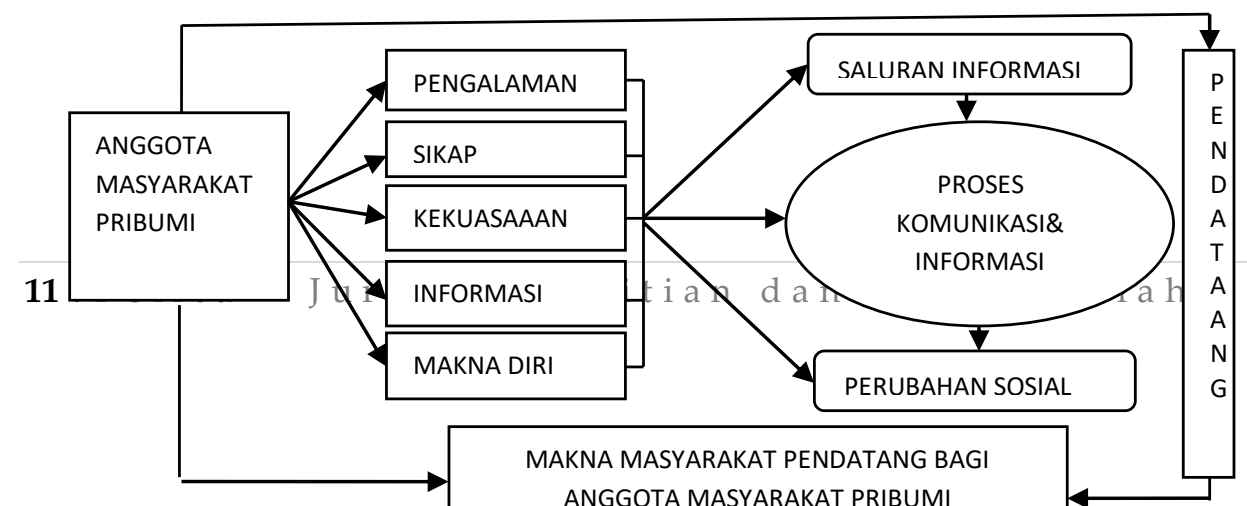




\section{Gambar 3}

Model anggota masyarakat pribumi memaknai masyarakat pendatang Sumber: Modifikasi Peneliti

\section{E. KESIMPULAN}

Berdasarkan hasil kajian yang telah dikemukakan berupa hasil dari pembahasan data dan informasi yang telah diperoleh di lokasi penelitian, maka dapat disimpulkan beberapa temuan sebagai berikut:

1. Masyarakat pribumi memaknai dirinya sebagai pemilik wilayah, putera asli daerah yang lebih layak dan adil ketika menjadi pemimpin, dan memaknai dirinya sebagai orang yang lebih religius, lebih jujur sebagaian yang lain memaknai dirinya sebagai pemalas dan pembual.

2. Masyarakat pribumi memaknai informasi yang diperoleh tentang masyarakat pendatang secara beragam sebagain memaknai informasi sebagai sebuah kebenaran sehingga membuat pribumi memaknai pendatang sebagai penjajah, pengeretan, sering membuat masalah tidak jujur dan takut berterus terang, namun bagi sebagain yang lain informasi tidak cukup kuat merubah persepsi mereka terhdap pendatang karena masyarakt pendatang masih dinilai lebih banyak memiliki sisi positif seperti dianggap pekerja keras, rajin dan sederhana. 
KONSTUKSI PEMAKNAAAN MASYARAKAT PRIBUMI:

MAKNA MASYARAKAT PENDATANG BAGI ANGGOTA MASYARAKAT PRIBUMI DESA NEROKTOG KECAMATAN PINANG KOTA TANGERANG

Een Irianti

3. Masyarakat pribumi memaknai pendatang sebagai pekerja keras yang mandiri, tidak mudah mengeluh, memiliki mental yang kuat, memiliki kepedulian yang tinggi kepada keluarga, irit, dan sederhana, di sisi lain ada juga yang memaknai pendatang sebagai orang yang sombong dan pelit.

\section{Referensi}

Adian, D. G. (2002). Menyoal Objektifitas Ilmu Pengetahuan. Traju: Jakarta.

Arifin M.T. (1999). "Kebudayaan Kraton dan Perubahan Masyarakat: Perspektif KGPAA Mangkunegoro". (Solo: makalah dalam simposium nasional).

Berger, P. L., \& Luckman, T. (1990). Tafsir Sosial Atas Kenyataan: Risalah Tentang Sosiologi Pengetahuan (diterjemahkan dari buku asli The Social Construction of Realiti oleh Hasan Basari). Jakarta: LP3ES.

Eriyanto. (2004). Analisis Wacana, Pengantar Analisis Isi Media. Yogyakarta: LKIS.

Lexy, M. J. (1989). Metode Penelitian Kualitatif, Bandung: PT. Remaja Rosdakarya.

Lexy, M. J. (2006). Metode Penelitian Kualitatif, Bandung: PT. Remaja Rosdakarya.

Lexy, M. J. (2005). Metode Penelitian Kualitatif, Bandung: PT. Remaja Rosdakarya.

Lexy, M. J. (2009). Metode Penelitian Kualitatif, Bandung: PT. Remaja Rosdakarya.

Noeng, M. (1998). Filsafat Ilmu: telaah sistematis fungsional komparatif, (Yogyakarta: Rake Sarasin.

Parsudi, S. (1999). Dari Monokultularisme, Jurnal Studi Amerika.

Rakhmat, K. (2008). Teknik Praktis Riset Komunikasi. Jakarta: Kencana Prenada Media Group

Stephen, L. W. (1999). Theories of Human Communication ed.6rd, California Wadsworth.

Sendjaja, S. Dj. (2007). Teori Komunikasi. Jakarta: Universitas Terbuka.

Sukamdi. (2002). "Konflik dan Masalah Pengungsi di Indonesia". Pusat Studi Kependudukan dan Kebijakan Universitas Gajah Mada. Hlm. 